\title{
A CATALOGUE OF AUDITORY AND VISUAL COMMUNICATORY TRAITS IN THE INDIAN EAGLE OWL BUBO BENGALENSIS (Franklin, 1831)
}

\author{
Mario Eric Ramanujam
}

Pitchandikulam Bio-Resource Centre, Auroville, Puducherry 605101, India

Email: tdef@auroville.org.in; ericramanujam@yahoo.co.in

\begin{abstract}
Vocalisations (auditory communication) and displays (visual communication) of Bubo bengalensis were recorded in the field over a period of 78 months. This disclosed 18 distinct behavioural traits - nine auditory and nine visual. None of these components were solitary units; each led on to another, increasing in intensity and was linked by short duration transition phases. A combination of both auditory and visual displays was found to be the most effective. Three distinct patterns of behaviour were discernable. Their causations, emphasising motivational and phylogenetic elements, are discussed here.
\end{abstract}

KEYWORDS

Behaviour, Bubo bengalensis, communication, visual display, vocalisation

The typical distinguishing call (which is incidentally the male's long call) has been well documented (Ali, 1969, 1996; Ali \& Ripley, 1987; Dharmakumarsinhji, 1954, 1964; Grimmet et al., 1998; Kazmierczak, 2000; Roberts, 1991; Whistler, 1986) Though hissing and bill clapping have received attention (Ali \& Ripley 1987; Whistler, 1986), most other auditory communications remain unknown. In fact it is only recently that documentation of the full range of vocalisations of some south and south-east Asian species of Strigidae have been undertaken (Boonsong \& Round, 1991; Roberts \& King, 1986). The spectacular intimidatory display of Bubo bengalensis has been recorded (Ali \& Ripley, 1987), but this was just a brief note of casual observations. A preliminary survey of the taxon in captivity (Ramanujam, 2000) served to sort out and categorise characteristics and mechanisms. The dynamics of the long call and certain vocalisations and displays employed by nestlings and adults in inter-specific intimidatory behaviour in the field were investigated and reported earlier (Ramanujam, $2003 \mathrm{a}, \mathrm{b}, \mathrm{c})$.

The objectives of this study were to (1) document and describe the communicatory behaviour of Bubo bengalensis, (2) analyse their functions, and (3) call attention to certain features, especially causation, which is not fully understood - for example, dual motives for employing the same communicatory device.

\section{Methods}

A number of ravines extend from Kalapet $\left(12^{\circ} \mathrm{O} 1^{\prime} \mathrm{N} \&\right.$ $\left.79^{\circ} 51^{\prime} \mathrm{E}\right)$ near the seashore, south-westwards through the Auroville plateau to the Aranya-Merveille area $\left(11^{\circ} 58^{\prime} \mathrm{N} \&\right.$ $79^{\circ} 46^{\prime} \mathrm{E}$ ) adjacent to Ousteri lake - all in a radius of 10 to $15 \mathrm{~km}$ from Puducherry city. Though most of these areas are environmental disasters, a few still contain a wealth of biota including resident breeding Bubo bengalensis.

Field studies centred around five breeding pairs and their young from June 1997 to December 2003 - a period of 78 months $\left(6^{1 / 2}\right.$ years). Bird watching sessions were concurrently held along with ecological studies. The tape playback method (Bergerhausen \& Williams, 1988; Falls, 1982; Martin, 1986) was used to identify individuals and monitor responses. Behaviour at the nest was intensively monitored from 16 March - 19 April 1998 at Kalapet, 3 March - 7 April 2001 at Merveille, 5 April - 21 May 2002 at Aranya and 4 January - 16 February 2003 at Success.

Ethological studies create special problems due to a lack of established nomenclature. For example it was not at all certain as to what was indicated by "distraction displays in January near the nest" (Vyas, 1996) - were they the displays described by Dharmakumarsinhji (1964) or by Ramanujam (2003b)? Misnomers also exist as in the case of "territorial call”, "recognition call”, etc (Ramanujam, 2000) where functions were poorly understood. To remedy this the nomenclature used in this report is documented herewith. Some of the calls, postures and displays have dual and multiple motivational and functional features, while those of others are not immediately apparent. A typical case in point is the multiple function of the begging call, wherein the call is not only directed at the parents, but is also performed in their absence and used as a source of information about the willingness of siblings to contest the next delivered prey item - the 'sibling negotiation hypothesis' (Roulin et al., 2000). As studies are still far from complete in understanding the dynamics of communicatory behaviour, tentative terms composed of elements of recognizable patterns have been used in most instances. Thus many terms used in a previous paper have been revised. Exceptions to this are behavioural traits controlled by a single motivational factor where causations are immediately obvious - for example, alarm calls and intimidatory displays.

\section{Results}

Description of the units of communication

Long call: It has been well described as a "deep, resonant, hollow bu-bo (accent on second syllable much prolonged) repeated at intervals; not particularly loud but with a curious penetrating and far carrying quality" (Ali \& Ripley, 1987). This is the typical rather melodious two-syllabled male call which was clearly distinguishable from the shorter, harsher female call. Every time the call was made the gular region was inflated making the white throat patch flash conspicuously, and the tail was raised and lowered (Fig 2a). Studies on the white throat patch ('badge') of the Eurasian Eagle Owl Bubo 
bubo has shown that it is important as a signalling device and its reflective properties increased during the territorial-mating period and females showed higher values of brightness than males (Penteriani et al., $2000 \mathrm{a}, \mathrm{b}$ ). It is not unlikely to assume that the flashing throat patch acts in the same way in Bubo bengalensis. Until recently, Bubo bengalensis was considered a sub-species of the Eurasian Eagle Owl Bubo bubo, and the calls of the two were assumed to be the same (Ali \& Ripley, 1987). In actual fact the calls are quite different. While the call of Bubo bubo can best be described as oohu-oohu-oohu, this taxon's call is best represented as bu-whooh. Rasmussen \& Anderton (2005) too prescribe to this theory.

This call has already been analysed (Ramanujam, 2003a), hence only the highlights need to be reiterated here. Increased frequency of calling was recorded at dusk by males - up to 70 calls between 1800-1900hr (lowest frequency was between 2300-0300hr). These calls directed towards other males in defence of territory, act as a space defence mechanism. Females also called on sighting mates, but if the males approached they were pugnaciously repulsed. Increased frequency of calling by both sexes occurred during courtship when they kept calling back and forth - over 70 calls per bird were recorded between $2100-2200 h r s$. This reversal of function of the long call (which hitherto acted as spatial defence) had the effect of bringing the sexes together and enhancing pair bonds. Very few calls, or none at all, were recorded from the time incubation began to the time young left the nest. 'Floaters' (non-territorial adults) did not employ this call.

Intermediate call: A shortened, softer version of the long call - it can best be described as a semi-monosyllabic whoo. This call was very obvious at the nest site when parents perceived each other and was also employed by the females when approaching nestlings. Interestingly, as long as the females remained at the nest, the males did not try to feed their progeny and dropped off food at a particular place within the reach of the females. At first the females retrieved food, but soon enough the belligerent youngsters found these food caches by themselves. At about this time the males too commenced feeding the hungry 'branchers'. No sounds emitted by the parents were audible during the feeding frenzy, but it could just be possible that this vocalisation by adults could have been drowned out by the youngsters' hunger calls.

Short call: This is a soft, rapidly repeated $k u k-k u k-k r k-r k-$ $r k \ldots$ Juveniles frequently vocalized like this on sighting parents. In adults it was particularly enhanced, almost continuous, during the courtship period and both preceded and followed the long call. This call of inter-individual value has a distance reducing element. It was also employed by crouching male when threatened by larger female, and as such also has elements of appeasement and/or submissiveness.

Begging call: A harsh throaty growl like wharr or gruu. Young owls over 25 days old were frequently heard producing this call - over 250 calls per hour. In fact, when young were being fed by parents this call could be heard throughout the hours of darkness and sometimes during the day, especially in overcast conditions. Though the call reduced in intensity and frequency after being fed, it did not stop and continued throughout the night. The young of Bubo bubo too produce a
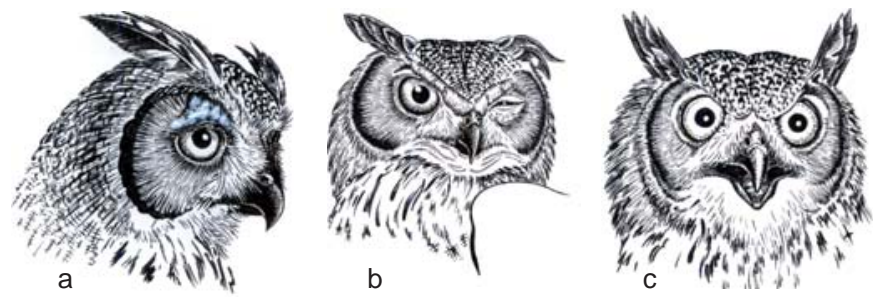

Figure 1. Positons of 'Horns' $a$ - in respore; $b$ - intermediate; $c$ - when excited

similar sounding call and this is used by researchers to find nesting sites (Kranz, 1971; Penteriani et al., 2000; Penteriani et al., 2002; Mysterud \& Dunker, 1982).

Alarm call 1: A startling harsh and loud three-syllabled Keaou-kak-kak or Nyak-nyak-nyak. It is probably this call that has been described as "very weird and ominous" (Dharmakumarsinhji, 1964). Instances of such behaviour were occasionally observed in both sexes when they perceived humans walking about in the ravines outside the breeding season. It was frequently employed by the females when they detected this investigator approaching nests. When young were in or around the vicinity of the nest site, the female parent remained in a vantage position frequently giving this call and was probably the time "when disturbed by day it will sit on a rock bowing and squawking at the intruder" (Whistler, 1986).

Alarm call 2: Male owls which did not occupy the nest site with females and young, but were perched on nearby vantage points produced a single syllabled soft, bark-like kow when they detected this investigator.

Chick-like vocalisations: Typical squealing noises. Employed by nestlings when being fed by parents. It was also heard during feeding when the crouching females produced this sound. This begging submissive gesture acts as a releaser and triggers the feeding instinct.

Hissing: A sound emitted with open beak (Fig. 1c). It denotes annoyance and accompanies all agnostic behaviour, always preceding and accompanying bill clapping. As such it is meant to have a deterrent value and acts as a space defence mechanism.

Bill clicking: It is produced by the lower mandible being extended over the hook of the upper, pressed hard, and withdrawn at speed to produce an audible clap. It denotes a high degree of annoyance and accompanies and precedes all agnostic distance increasing and inter-specific displays.

Positions of 'horns': Many species of birds have erectile feather crests or aigrettes adorning their heads. In the Strigidae they take the form of 'horns' or 'eartufts' (misnomers actually) which can be raised or lowered. It was noticed that the positions of these horns were directly related to the psychological state of the individual at any given time. When in repose they drooped considerably (Fig. 1a), but when excited they were fully erected (Fig. 1c). Many intermediate transition phases exist, often one half behaving contrary to the other (Fig. 1b).

Sleeked plumage: Adopted by adults when perched in a tree during the day or sitting 'cat-like' on the ground or ledge on cliff face, and also by nestlings in the crouching posture 


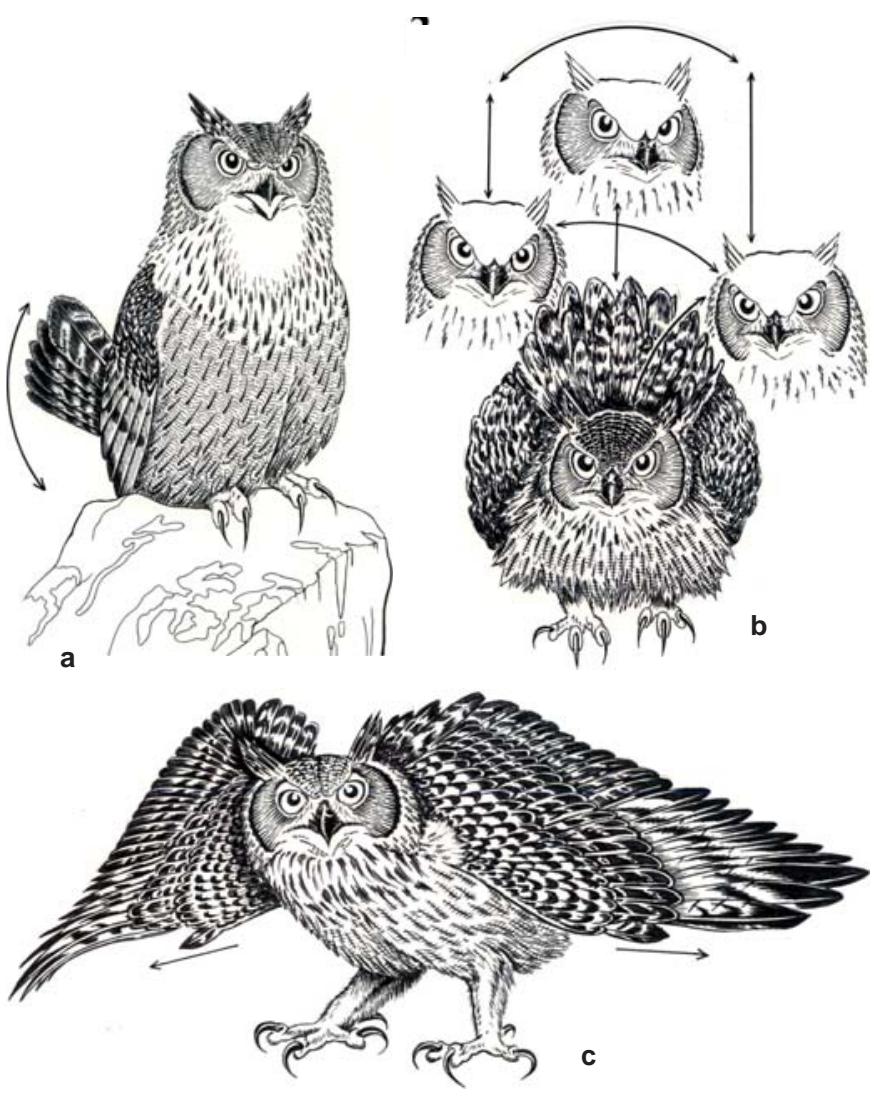

Figure 2. Intra-specific agnostic behaviour by a territorial male towards intruder

a - on sighting intruder the territory holder increased frequency of calling; $b$ - began bobbing, simultaneously erecting body plumage; $c$ - the threat display succeeded in putting the intruder to flight

(Fig. 4 a). It is a concealing attitude with the feathers drawn in tightly giving the birds a sleek look. The owls sit motionless, relying on their cryptically coloured plumage for camouflage. The effectiveness of this posture can be gauged by the fact that crows flying overhead never once detected the presence of nestlings, though they remained in relatively exposed positions.

Ruffled plumage: When approached by intruders (potential predators, humans and unknown owls) the owls stared unblinkingly at them and simultaneously erected body plumage making them appear larger than normal. This display was adopted to intimidate intruders.

Bobbing or Bowing: When approached by intruders, the owls stared fixedly at the objects of interest, erected body plumage, bowed low and then erected the body often craning their necks. On occasion they shuffled from foot to foot. This motion is to gain better depth perception (and was observed prior to launching attack on prey, but on these occasions the plumage was not erected).

Crouching: A low subordinate crouching posture. Nestlings assumed this posture and remained very still for purposes of concealment (Fig. 4a), but adults employed it for purposeful reasons. Outside the breeding season it was employed by smaller males on being threatened by their mates when they

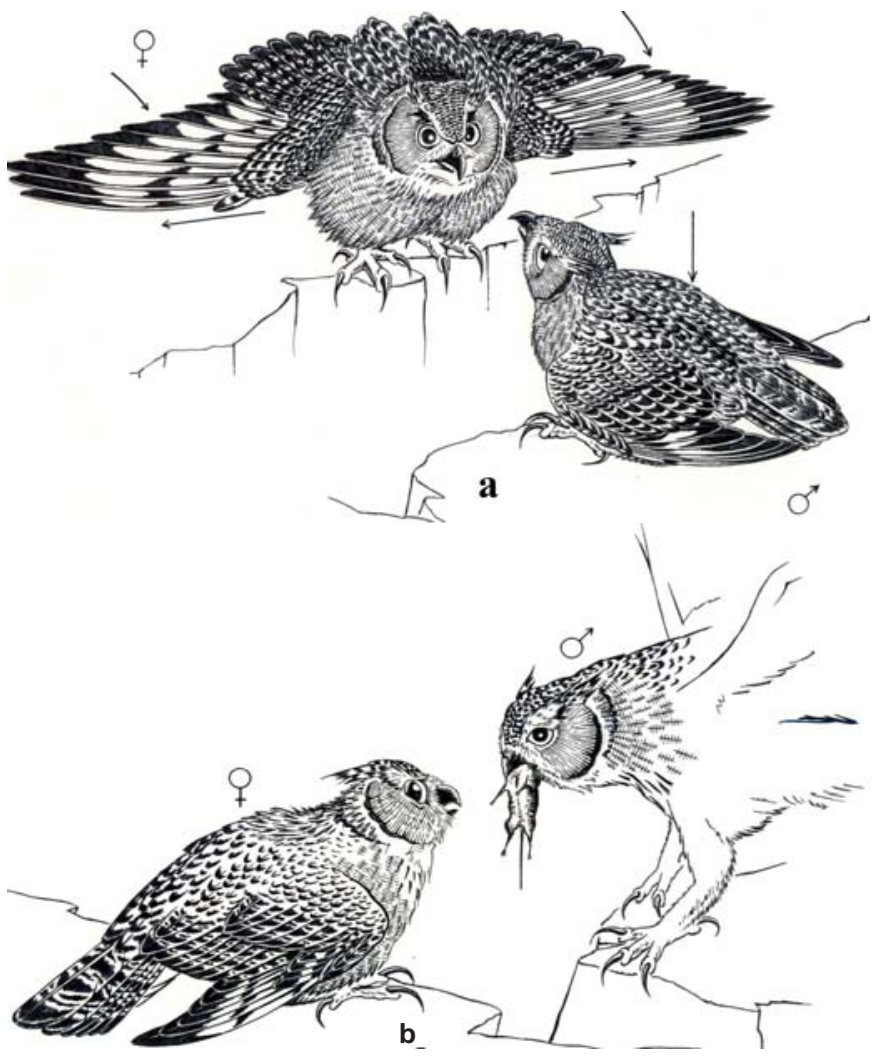

Figure 3. Intra-specific behaviour in an established pair a - outside the breeding season the female repulsed the advances of the male by displaying threateningly; the male adopted the crouching posture; b - during courtship the female adopted the crouching posture which induced the male to feed her. attempted to approach (Fig. 3a). A reversal of roles took place during the courtship period when dominant females assumed this posture (Fig 3b). It was also adopted by females at the nest when receiving food from their mates. As such, this posture has features of appeasement and is employed to cross purposes. Outside the breeding season it is a subordinate posture adopted by males to prevent being attacked by larger females, but during the breeding season it is adopted by females as a distance reducer and triggers feeding behaviour in males.

Face away: In cases of agnostic intra-specific behaviour in established pairs outside the breeding season, the threatening birds (females) were observed to face away, though their bodies remained directed towards the subordinate males. This allowed the males to rise and make good their escape.

Jabbing: This is a fast thrust of the beak combined with a biting action in the direction of the mate, but stops short of touching. It was observed to be employed by males in confrontation with their mates and followed the crouching posture after the threatening females faced away. The criteria for this action remains in doubt - it could simply be a reflexive displacement action reflecting the birds' emotional state.

Intimidatory display: A display of inter-specific value, it was employed by nestlings over 15 days old and by females at the nest against human observers. The owls, on being 


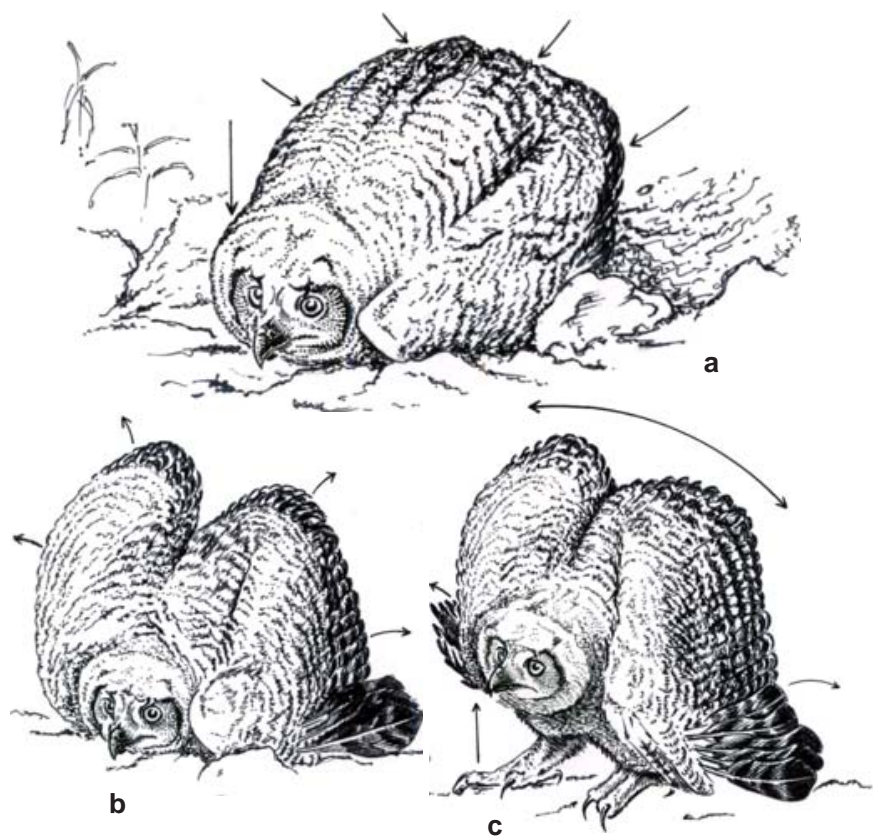

Figure 4. Inter-specific intimidatory behaviour by nestling towards human intruder

a - on sighting human the nestling crouched low and drew in its body plumage; $b$ - it began hissing, bill clapping and slow erection of body plumage, till it reached this transtion phase at 1.5m.; c - at less than $1 \mathrm{~m}$. it adopted the full intensity intimidatory display

confronted by intruders, stared fixedly at them, leant forward, swayed from foot to foot, swelled feathers to their full extent and opened their wings outward - thus making themselves appear many times their usual size (Fig. 4c). Loud hissing and bill clapping enhanced the impression of ferocity. The action was a bluff, the intent being to keep intruders at bay and was sufficient to frighten away most animals including humans. It also served as a diversionary tactic, the birds making good their escape if pressed. Never have the displaying birds been known to attack, even when the young were presented with the investigator's fingers on quite a few occasions.

Threat display: Often confused with the intimidatory display, but the wings were held fully extended, with the elbow and wrist relatively straight (Figs. 2c, 3a). Various intensity phases existed - the more vertically the wings were held the least intense was the threat; the most intense threat was the one with the wing face flat and parallel to the ground. Here the motive was to attack and the displaying birds did so unhesitatingly if the stimulus persisted. A display of intraspecific value, it is used by males in defence of territory and by females to repulse mates outside the breeding season.

Dharmakumarsinhji (1964) documented his approach to a nest site with young and the resultant female parent's behaviour as such: "As I approached, the parent flew a little way off and feigned to be wounded. Coming to ground she began flapping her wings from side to side on the ground and at the same time squealing." This behaviour was not recorded during this study.
Combinations and progressive sequences of signalling devices

Displays and calls are not solitary units and are not employed as such. Each entity leads on to another in a process which develops gradually, often through a series of intention (or transition) movements that become more complete and persist for as long as the stimulus remains. In such cases a combination of both auditory and visual signals are the most effective. The classical behaviour by a male in defence of its territory (Fig. 2) is a case in point: the long call perceived from a distance is a deterrent and is useful in preventing intrusions. Yet, if another male approaches, the territory holder will declare its presence and intent by increased calling and bobbing, simultaneously erecting body plumage, hissing and bill clapping. If the intruder insists in staying the threat display goes into force, escalating from the least offensive to the most intense. Justification for these intensity types is that various types of intruders exist, ranging from the casual visitor to the would be settler, who in trying to occupy territory is prepared to stand its ground. The first flees at the slightest warning, the other needs strong language.

Sequences of behaviour observed during the study period are documented in Table 1.

\section{Patterns of behaviour}

Patterns of behaviour can be categorized under three broad groups according to their functions.

Intra-specific distance-increasing or spacing-out behaviour: These agnostic or semi-agnostic signalling devices derive characteristics from pressure favouring conspicuousness; the motivation being to prevent approach. The behaviour by a territorial male towards an intruding floater is a typical case in point.

The causation for the female employing agnostic behaviour towards its mate outside the breeding season is directly related to its endocrine state. Outside the breeding season the sexes live solitary lives (though a pair occupies the same territory, the female avoids direct contact with its mate). The female advertises its presence with a long call directed towards its mate, but if the male persists in approaching closely it is repulsed using the same set of devices as a male would use against another male.

Intra-specific distance-reducing behaviour: With the advent of the breeding season it is imperative for the sexes to come together and the female's endocrine state allows this. Yet, as the male (which has been strongly repulsed earlier) may be reluctant to take liberties, a distinct set of signalling devices that reverses the pecking order are now employed by the complaisant female. These encourage the male's overtures and enforce the pair bond. All these displays favour insconspicuousness (contrary to distance-increasing behaviour which favours conspicuousness).

A threatening conspicuous gesture usually elicits a submissive inconspicuous gesture in an established pair. Appeasement gestures like the male's contain an element of fear and the tendency to flee is in conflict with the tendency to stay, hence a compromisory crouching display. 
Table 1. Some observed sequences of Bubo bengalensis behaviour under various empirical conditions

\begin{tabular}{|c|c|c|c|}
\hline & Stimulus & Progressive sequences of signalling devices & Result \\
\hline 1. & Playing male long call in the field & Male: Increased frequency of calling & -- \\
\hline 2. & $\begin{array}{l}\text { Neighbouring male approached } \\
\text { boundary of its territory }\end{array}$ & Male: Increased frequency of calling & $\begin{array}{l}\text { Both males sat at the edges of } \\
\text { their territories calling for sometime }\end{array}$ \\
\hline 3. & Territory encroached uponby floater & $\begin{array}{l}\text { Male: Increased frequency of calling - Bobbing, simultaneously } \\
\text { erecting body plumage - Hissing - Bill clapping - Threat display }\end{array}$ & Intruder flew away \\
\hline 4. & $\begin{array}{l}\text { Female approached by male outside the } \\
\text { breeding season }\end{array}$ & $\begin{array}{l}\text { Female: Long call - Erecting body plumage - Hissing - Bill clapping } \\
\text { - Threat display - Male: Crouching - Female: Face away }\end{array}$ & Male flew away \\
\hline 5. & $\begin{array}{l}\text { Female approached by male during } \\
\text { courtship with food }\end{array}$ & $\begin{array}{l}\text { Long call by both sexes had been going on by prior To this - } \\
\text { Male: Short call - Female: Crouching - Chick-like vocalisations }\end{array}$ & Male flew away \\
\hline 6. & $\begin{array}{l}\text { Male approached incubating female at } \\
\text { nest site with food }\end{array}$ & $\begin{array}{l}\text { Male: Intermediate call - Short call - Female: Crouching - } \\
\text { Chick-like vocalisations }\end{array}$ & Male flew away \\
\hline 7. & $\begin{array}{l}\text { Female approached } 5 \text { day old Nestling } \\
\text { with food }\end{array}$ & $\begin{array}{l}\text { Female: Intermediate call - Short call - Nestling:Chick-like } \\
\text { vocalisations }\end{array}$ & Female fed nestling \\
\hline 8. & $\begin{array}{l}\text { Female approached nestlings over } \\
15 \text { days old with food }\end{array}$ & $\begin{array}{l}\text { Female:Intermediate call - Short call - Nestlings: increased } \\
\text { frequency of Hunger call (accompanying the unusual rush for } \\
\text { food) - No other vocalizations could be heard in the melee }\end{array}$ & $\begin{array}{l}\text { Female fed closest nestling - } \\
\text { Others continued Hunger call. }\end{array}$ \\
\hline 9. & Adult owl approached by observer & Ruffled plumage - Hissing - Bill Clapping & Owl flew away \\
\hline 10. & $\begin{array}{l}\text { Observer crouched in bushes awaiting } \\
\text { male on signal rocks }\end{array}$ & Male (on detecting the observer): Alarm call 1 & Owl flew away \\
\hline 11. & Incubating female approached by observer & Ruffled plumage - Hissing - Bill clapping & Owl flew away \\
\hline 12. & $\begin{array}{l}\text { Nest site with female and young } \\
\text { approached by observer }\end{array}$ & $\begin{array}{l}\text { Male: Alarm call2 - Hissing - Bill clapping - Alarm calls } 1 \\
\text { and } 2 \text { - Female: Alarm call } 1 \text { - Intimidatory display - Flies off } \\
\text { nest and continues Alarm call } 1\end{array}$ & $\begin{array}{l}\text { Male: Mobs observer - Observer } \\
\text { retreated }\end{array}$ \\
\hline 13. & 5 day old nestling approached by observer & Crouching & $\begin{array}{l}\text { Observer collected data and } \\
\text { retreated. }\end{array}$ \\
\hline 14. & $\begin{array}{l}17 \text { day old nestling approached by } \\
\text { observer }\end{array}$ & $\begin{array}{l}\text { Crouching - Hissing - Bill clapping - Ruffled plumage - } \\
\text { Intimidatory display }\end{array}$ & $\begin{array}{l}\text { Observer collected data and } \\
\text { retreated }\end{array}$ \\
\hline
\end{tabular}

Inter-specific or Defensive behaviour: These signalling devices all function as distance increasers and favour conspicuousness and combine features of intra-specific distance increasing behaviour though targeted towards other species (potential predators). A perfect example is the intimidatory display employed by nestlings on being approached by humans.

\section{Discussion}

Though owls have simple calls in comparison to the Oscines, they have substantial vocal organs (Perrins, 1976) and are capable of more diverse, though less complex vocalisations. These acoustic features are adaptations to the environment and characteristic of the species. For example, the rationale for the "curious penetrating quality" of the long call (Ali \& Ripley, 1987) may be that high pitched calls common to most birds are particularly inconvenient in the ravines as these calls do not carry far and are doused by bushes and rocky outcrops; hence these birds defending large territories and needing to be heard at a distance have evolved this characteristic acoustic quality. Calls at short range of inter-individual value do not have to carry far and can be softer and more complex than long range communication.

All birds assume characteristic postures in the normal processes of their daily lives, that though unintentional, serve an important purpose (like the cryptic sleeked posture of ground nesting owls) which have distinct survival value. Another set of displays could be said to be intentional, in the sense that they perform important functions when directed towards others both in the inter-specific and intra-specific spheres. The use of identical displays in other owl species has been documented in earlier articles (Ramanujam, 2000, 2003b). This striking feature shows a high degree of ontogenetic stability in the sense of resistance against environmental modification. Phyllogenetically, the similarities in their function and mechanism, together with their continuous occurrence in the group, strongly supports the conclusion that the Strigidae are a monophyletic group. This confirms the theory that ritual displays are more useful as taxonomic characters than all other forms of behaviour (Lorenz, 1941). Though attempts have been made to show relationships in owls using vocalisations (Marshall, 1966, 1967), these have little value for discerning taxonomic relationships beyond the generic level (Lanyon, 1969; Thieleke, 1964; Thorpe, 1961).

As mentioned earlier, some signalling devices function at cross purposes - eg., the long call and crouching. This behaviour depending upon stimulus and endocrine state, does lead us to the logical conclusion of biological function, but the rationale for the employment of the same device to cross purposes and their causation still remains inconclusive. Called 'releasers' (Lorenz, 1935) and 'signalling devices' (Tinbergen, 1959) knowledge of their causation has remained superficial and fragmentary. Motivational studies are still at an early stage and as we are still far from understanding the signals of 
animals in general, and owls in particular, these forms of reasoning can do little more than indicate evolutionary origin and function. Amplification by tests is the need, and now that the problem is seen more clearly, such tests could be possible and promising.

\section{REFERENCES}

Ali, S.(1969). Birds of Kerala. $2^{\text {nd }}$ Edition of The Birds of Travancore and Cochin. Oxford University Press, 444pp.

Ali, S. (1996). The Book of Indian Birds. $14^{\text {th }}$ Revised and Centenary Edition. Oxford University Press, 354pp.

Ali, S. \& S.D. Ripley (1987). Compact Handbook of the Birds of India and Pakistan Together With Those of Bangladesh, Nepal, Bhutan and Sri Lanka. Okford University Press, Dehli, 737pp.

Bergerhausen, W. \& H. Willelm2s (1988). Methodik und Effizienz der Bestandkontrolle einer Population des Uhus (Bubo bubo L.). Charadrius 24: 171-187.

Boonsong, L. \& P.D. Round (1991). A Guide to The Birds of Thailand. Saha Karn Bhaet, Bangkok, pp.170-176.

Dharmakumarsinhji, R.S. (1954). The Birds of Saurashtra. Times of India Press, Bombay.

Dharmakumarsinhji, R.S. (1964). The Indian Great Horned Owl (Bubo bubo bengalensis (Frankl.)). Journal of the Bombay Natural History Society 61: 174-177.

Falls, J.B. (1982). Individual recognition by sounds in birds. Acoustic Communication in Birds 237-238.

Grimmet, R., C. Inskipp \& T. Inskipp (1998). Birds of The Indian Subcontinent. Oxford University Press, New Dehli, 882pp.

Kazmierczak, K. (2003). A Field Guide to The Birds of India, Sri Lanka, Pakistan, Nepal, Bhutan, Bangladesh and The Maldives. Om Book Services, New Dehli, 352pp.

Kranz, P. (1971). Nagot om berguvens aktivitat och foda. Faglar $i$ Sormland 4: 13-23.

Lorenz, K. (1935). Der Kumpan in der Umwelt des Vogels. Journal fir Ornithology 89: 194-294.

Lanyon, W.E. (1969). Vocal characters and avian systematics. Bird Vocalisations (Ed. R.A. Hinde), 291-310.

Marshall, J.T. Jr. (1966). Relationships of certain owls around the Pacific. Natural History Bulletin Siam Society 21: 235-242.

Marshall, J.T. Jr. (1967). Parallel variation in north and middle American screech owls. Monographs of the Western Foundation of Vertebrate Zoology 1: $1-72$.

Martin, G. (1986). Sensory capacities and the nocturnal habit in owls. Ibis 128: 266-277.

Mysterud, I. \& H. Dunker (1982). Food and nesting ecology of the Eagle Owl, Bubo bubo (L.), in four neighbouring territories in southern Norway. Swedish Wildlife Research (Viltrevy) 12.

Perrins, C. (1976). Birds: Their life - their ways - their world. Harry N. Abrams Inc., N.Y., 412pp.

Penteriani, V., M. Gallardo \& H. Cazassus (2000). Diurnal vocal activity of young Eagle Owls and its implication in detecting occupied nests. Journal of Raptor Research 34: 232-235.

Penteriani, V., M. Gallardo \& P. Roche (2002). Landscape structure and food supply affect Eagle Owl (Bubo bubo) density and breeding performance: A case of intra-population heterogeneity. Journal of Zoology, The Zoological Society of London 257: 365-372.

Penteriani,V., M. del Mar Delgado,C.Alonso-Alvarez \& F. Sergio (2006a). The importance of visual cues for nocturnal species: eagle owls signal by badge brightness. Behavioural Ecology 18: 143-147.

Penteriani,V., C. Alonso-Alvarez, M. del Mar Delgado, F. Sergio \& M. Ferrer (2006b). Brightness variability in the white badge of the eagle owl Bubo bubo. Journal of Avian Biology 37: 110-116.

Ramanujam, M.E. (2000). An attempt to rationalize on the vocalisations and displays of captive Indian Eagle Owls Bubo bubo bengalensis Franklin. Zoos' Print Journal 15: 269-274.

Ramanujam, M.E. (2003a). On the "Long Call" of the Indian Great Horned or Eagle Owl Bubo bengalensis (Franklin). Zoos' Print Journal 18:
$1131-1134$.

Ramanujam, M.E. (2003b). Inter-specific intimidatory behaviour in nestling Indian Eagle Owls Bubo bengalensis (Franklin). Zoos' Print Journal 18: $1213-1216$

Ramanujam, M.E. (2003c). Inter-specific intimidatory behaviour in adult Indian Eagle Owls Bubo bengalensis (Franklin) in defence of their nestlings. Zoos' Print Journal 18: 1343-1345.

Rasmussen, P.C. \& J.C. Anderton (2005). Birds of South Asia. The Ripley Guide Vol 1. Smithsonian Institution \& Lynx Edicions, Washington, D.C. \& Barcelona, 378pp.

Roberts, T.J. (1991). The Birds of Pakistan. Oxford University Press, 79 pp.

Roberts, T.J. and B. King (1986). Vocalizations of the owls of the genus Otus in Pakistan. Ornis Scandinavica 17: 299-305.

Roulin, A., M. Kolliker \& H. Richner (2000). Barn Owl (Tyto alba) siblings vocally negotiate resources. Proceedings of the Royal Society of London 267: 459-463.

Thielcke, G. (1964). Lautäusserungen der Vögel in ihrer Bedeutung für die Taxonomie. Journal für Ornithology 105: 78-84.

Thorpe, W.H. (1961). Bird Song. The biology of vocal communication and expression in Birds. Cambridge University Press; Cambridge Monographs In Experimental Biology, 12pp.

Tinbergen, N. (1959). Comparative studies of the behaviour of gulls (Laridae). The Animal in its World - Field Studies. George Allen and Unwin Ltd., London, pp.25-98.

Vyas, (1996). Checklist of the birds of the Delhi region: an update. Journal of the Bombay Natural History Socienty 93: 229.

Whistler, H. (1986). Handbook of Indian Birds (First published in 1928). Cosmo Publication, New Dehli, 423pp.

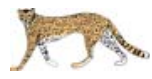

